\title{
STUDIES ON URINARY PEPTIDES ISOLATED FROM PATIENTS SUFFERING FROM BURNS
}

\author{
BY
}

\author{
S. BAAR \\ From the Medical Research Council Industrial Injuries and Burns Research Unit, Birmingham Accident \\ Hospital
}

(RECEIVED FOR PUBLICATION JUNE 24, 1955)

Dent (1948) first detected urinary peptides in cases of nephrosis using two-dimensional chromatography. Arneil and Wilson (1953) found a simiar "nephrotic" peptide spot on chromatograms obtained from the urines of patients suffering from oedema due to other causes, such as burns, scalds, or fractures. Barlow (1952) found that the blood of nephrotic patients showed a high antidiuretic activity.

The patients with burns whose peptide excretion was investigated all showed an oliguria of 0.5 to 1 litre a day (Bull and England, 1954). It therefore seemed reasonable to investigate chemical and physical properties of such urinary peptides and compare them with a material of high antidiuretic activity isolated from the posterior pituitary gland.

\section{Experimental}

The urine of patients of all ages suffering from burns extending over at least $15 \%$ of the body surface was collected during the first two days after injury. The specimens were preserved with chloroform thymol.

A modification of the method described by Grollman and Woods (1949) for the isolation of an antidiuretic principle from urine was employed.

The urine specimens were adjusted to $p \mathrm{H} 4.5$ with 1 g. glacial acetic acid. Norit, 1 g., washed with distilled water and acetone was added per $100 \mathrm{ml}$. urine. The mixture was then stirred for several hours, placed in the refrigerator overnight, and the supernatant decanted the next morning. The charcoal was washed with a small amount of water into a Büchner funnel and sucked as dry as possible. It was then resuspended in $10 \mathrm{ml}$. of glacial acetic acid per gram of charcoal originally added and stirred for several hours. This solution was filtered and the peptide precipitated by the addition of 5 volumes of ethyl alcohol and 5 volumes of ether. The precipitates were collected by centrifugation, washed twice with alcohol, once with ether, and dried in vacuo over anhydrous magnesium perchlorate. To purify the peptides, they were redissolved in a minimal amount of water and reprecipitated and dried as above. Posterior pituitary lobe powder (obtained from Paynes and Byrne Ltd.) was hydrolysed for 30 minutes in $10 \% \mathrm{v} / \mathrm{v}$ glacial acetic acid at $105^{\circ} \mathrm{C}$. The material obtained was purified as described above for the urinary preparation.

\section{Results}

The product was an almost colourless powder, and had an antidiuretic activity of approximately 200 units per gram. The purified urinary material showed an activity of less than 10 units per gram. The high activity of the hormone hydrolysate demonstrates that the conditions of hydrolysis and method of isolation did not destroy antidiuretic activity.

Both the urinary peptides and the hormone hydrolysate were freely soluble in distilled water, glacial

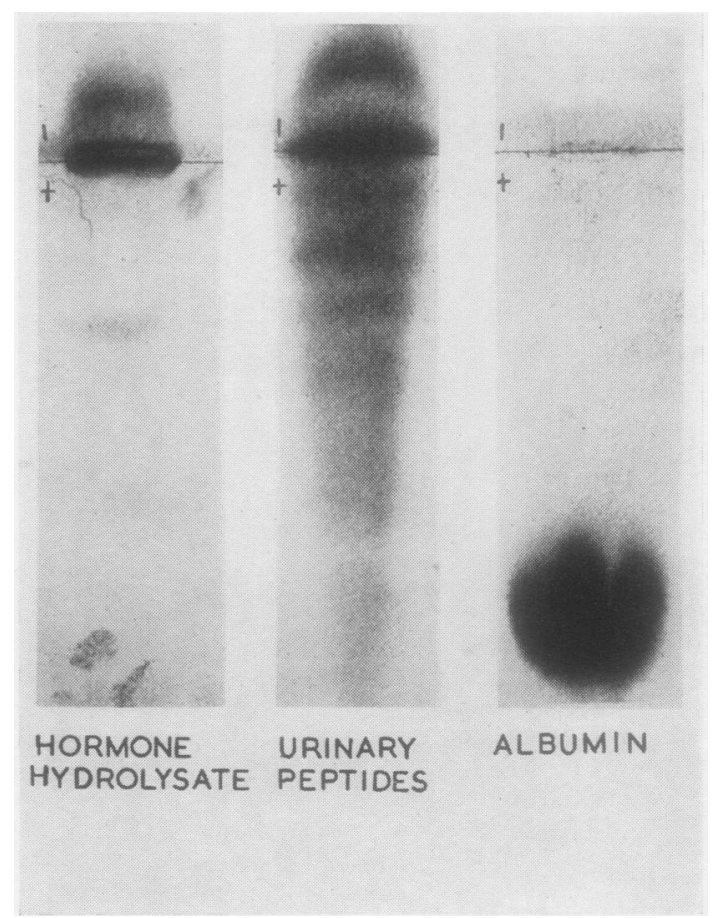

Fig. 1.-Electrophoretogram of urinary peptides and a hormone hydrolysate of high antidiuretic activity. 
acetic acid, and ammonia solution S.G. 0.88 . If, however, brought into solution in cold mineral acid, the materials could not be recovered unchanged. To identify the constituent amino-acids the materials were hydrolysed 24 hours in $6 \mathrm{~N}$ hydrochloric acid at $115^{\circ} \mathrm{C}$., the hydrolysate neutralized with silver carbonate and the supernatant chromatographed twodimensionally using phenol/ammonia/water and collidine/lutidine/water. The urinary material showed the following amino-acids : lysine, arginine, glycine, alanine, hydroxyproline, tyrosine, glutamic acid, least six components of the urinary material. Some corresponded with fractions obtained from the hormone hydrolysate, which was, however, less complex. A typical paper electrophoretic pattern is shown in Fig. 1.

This lack of homogeneity was confirmed by carrier displacement chromatography using a method similar to that described by Tiselius and Hagdahl (1950). Norit, $5 \mathrm{~g}$., and $5 \mathrm{~g}$. of "hyflo" were washed with alcohol and ether and air dried. A column $37 \mathrm{~cm}$. by $1 \mathrm{~cm}$. was used. The column was filled with the

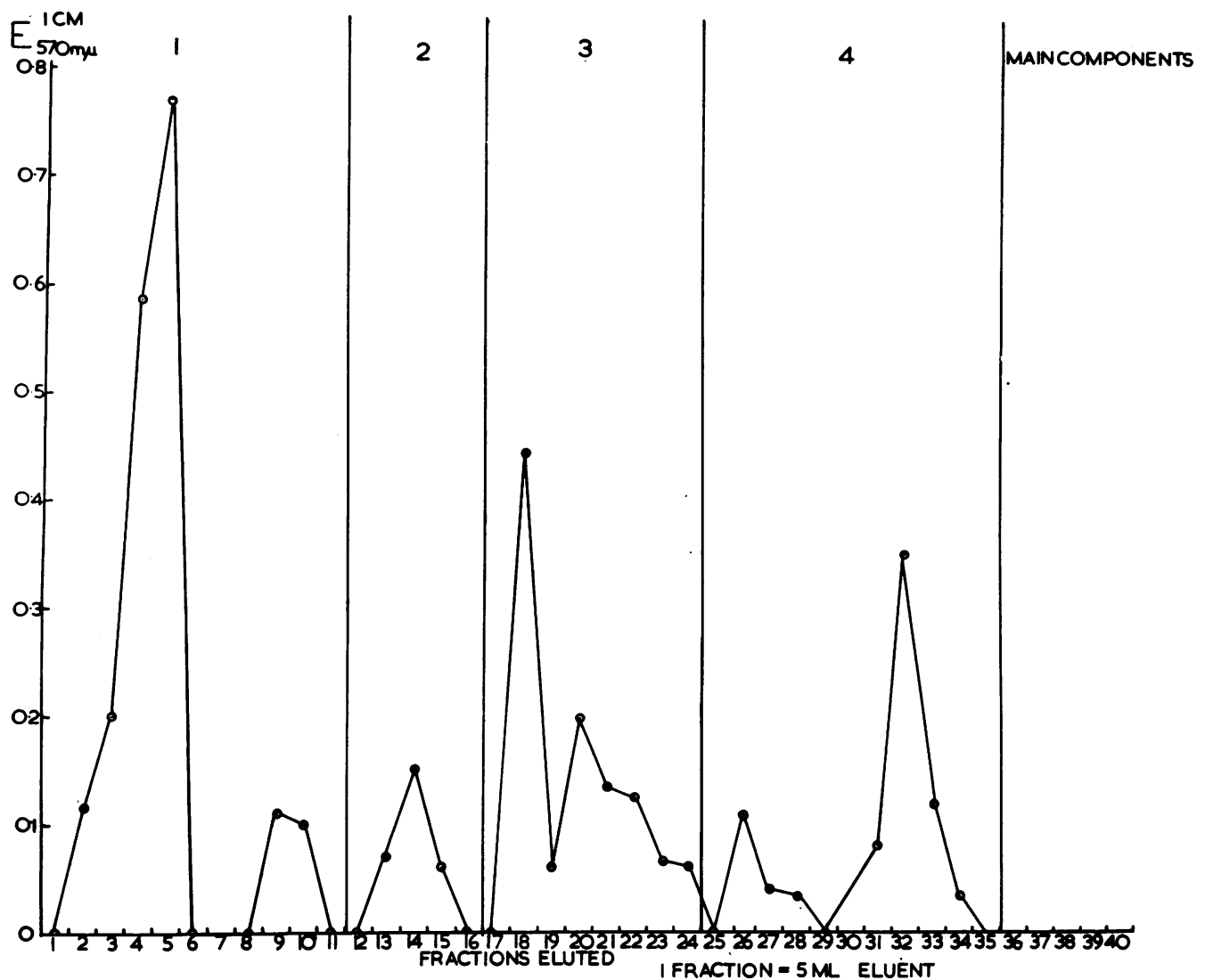

FIG. 2.-Fractionation of urinary peptides on a column of charcoal and "hyflo" supercel.

aspartic acid, serine, valine, and a weak spot for cystine (which was detected as cysteic acid). The hormone hydrolysate showed a similar amino-acid composition, but ornithine was found in addition and the spot due to cystine was considerably more intense. The non-hydrolysed materials, if run on chromatograms, with phenol-ammonia-water or butanol-acetic acid as solvent systems, travelled as long streaks with low ninhydrin staining intensity. This suggested inhomogeneity and moderately high molecular weights.

Electrophoretic separation on Whatman No. 3 filter paper in a $0.05 \mathrm{M}$ veronal buffer at $p \mathrm{H} 8.5$ and 0.27 $\mathrm{MA} / \mathrm{cm}$. when developed with ninhydrin showed at mixture as a paste in $0.1 \mathrm{~N}$ hydrochloric acid. To load the column $10 \mathrm{mg}$. of the urinary peptides was dissolved in a mixture of $8 \mathrm{ml} .1 \% \mathrm{v} / \mathrm{v}$ iso-amylalcohol and $2.5 \mathrm{ml} .1 \% \mathrm{v} / \mathrm{v} \mathrm{n}$-butanol. Slight suction was employed throughout and the components displaced with $0.1 \mathrm{~N}$ hydrochloric acid saturated with $\mathrm{n}$ benzyl-alcohol. Thirty-five $5 \mathrm{ml}$. fractions were collected and the amino-acid nitrogen determined according to the method described by Moore and Stein (1948). From Fig. 2 it becomes evident that the urinary material consisted of three major components and four minor components. These could be considered as four main components. Eluates corre- 


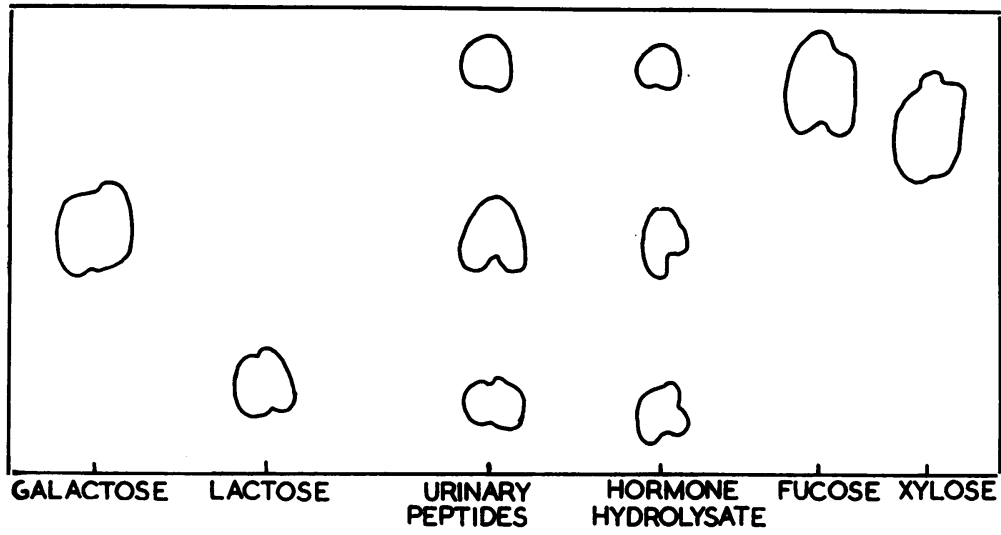

FIG. 3.-Typical chromatogram of hydrolysates of urinary peplides and hormone hydrolysate. values corresponded to those $\stackrel{\vec{\sigma}}{\overrightarrow{0}}$ of lactose, galactose, and fucose, their concentrations de- $\frac{\vec{s}}{\mathrm{~s}}$ creasing in the order stated. The tracing of a typical chromatogram is shown in $\frac{\overline{\bar{N}}}{\text {. }}$ Fig. 3. The carbohydrate content of the two prepara- $\mathbb{Q}$ tions was established by an elution method as described by Baar (1954). The total. carbohydrate content of the $\overrightarrow{\vec{\omega}}$ urinary material was $9.26 \%$, while that of the hormone hydrolysate was $8.56 \%$. No ? hexosamines could be de- 0 tected. The nitrogen and $\stackrel{N}{-}$ sulphur content were estab- $\vec{A}$ lished by a micro-Kjeldahl

sponding to these main fractions were pooled, concentrated in vacuo, redissolved in water, and paper electrophoretic patterns prepared. None of these main fractions did, however, run uniformly, although certain components appeared to be increased and others decreased.

An attempt was made to fractionate the urinary material by dialysis in "viscose" membranes. The solution was dialysed against water at approximately $5^{\circ} \mathrm{C}$. The dialysates were concentrated in vacuo and their nature checked by paper electrophoresis. Three hours' dialysis caused diffusion of amino-acids only, while after five hours some peptide had diffused. After 24 hours an equilibrium had been established. Dialysis therefore proved unsuitable for fractionation. All peptides were also precipitable by $5 \% \mathrm{w} / \mathrm{v}$ trichloracetic acid.

The effect of pepsin on the urinary material was studied as follows: $10 \mathrm{mg}$. was dissolved in $1 \mathrm{ml}$. $0.01 \mathrm{~N}$ hydrochloric acid and kept at $37^{\circ} \mathrm{C}$. in a waterbath. To stop the reaction the tube was immersed in ice-cold water and the material precipitated by the addition of 10 volumes of a 1:1 mixture of alcohol and ether, when $9.8 \mathrm{mg}$. was recovered and no change could be detected in the nature of the material by paper electrophoresis.

Both the posterior pituitary hydrolysate and the urinary material gave a positive Molisch reaction. Films of the substance in gelatine gave a positive periodic-acid-Schiff reaction. The nature of the carbohydrates present was therefore investigated. The materials were hydrolysed in sealed ampoules in $0.1 \mathrm{~N}$ hydrochloric acid for 60 minutes at $110^{\circ} \mathrm{C}$. The hydrochloric acid was removed in a vacuum desiccator over solid potassium hydroxide. The residues were water soluble and could be precipitated with 10 volumes of a 1:1 mixture of alcohol and ether. The carbohydrates were identified by paper chromatography using the ascending technique and the solvent system n-propanol:ethyl acetate: water7:1:2 (Albon and Gross, 1952). When stained with aniline hydrogen phthalate the urinary material and the hormone hydrolysate showed three spots whose $\mathbf{R}_{\mathbf{F}}$ method and by the method of Fiske and Subbarow (1925). The values obtained, together with the $\vec{r}$ carbohydrate partitions, are shown in Table I.

TABLE I

COMPOSITION OF URINARY PEPTIDES AND HORMONE HYDROLYSATE

\begin{tabular}{c|c|c|c|c|c}
\hline Substance & $\begin{array}{c}\% \\
\text { Nitroger }\end{array}$ & $\begin{array}{c}\% \\
\text { Sulphur }\end{array}$ & $\begin{array}{c}\% \\
\text { Lactose }\end{array}$ & $\begin{array}{c}\% \\
\text { Galactose }\end{array}$ & $\begin{array}{c}\% \\
\text { Fucose }\end{array}$ \\
\hline $\begin{array}{l}\text { Urinary peptide. . } \\
\text { Hormone hydroly- } \\
\text { sate . }\end{array}$ & 11.06 & 4.28 & 5.40 & 3.62 & 024 \\
\hline
\end{tabular}

To obtain further information on the urinary material it was fractionated with aqueous ethanol at $2^{\circ} \mathrm{C}$. The ethanol solutions were always adjusted to $p \mathbf{H ~} 3.5$ by the addition of glacial acetic acid. Urinary material, $497.5 \mathrm{mg}$., was shaken with $35 \% \mathrm{v} / \mathrm{v}$ ethanol at room temperature. Precipitation was completed in the refrigerator at $2^{\circ} \mathrm{C}$. for 24 hours. The insoluble material was separated by centrifugation in the refrigerator, washed with ether, and dried and weighed. The peptides still in solution were then precipitated with the excess precipitant and dried as before. These were weighed and considered as $100 \%$ starting material for the next fractionation. The results were calculated on that basis and are shown in Table II. The antidiuretic activities were tested in the alcoholized rat

TABLE II

FRACTIONATION OF URINARY PEPTIDES WITH AQUEOUS ETHANOL

\begin{tabular}{|c|c|c|}
\hline$\stackrel{\%}{\%}$ & Precipitated & $\begin{array}{c}\text { Activity } * \\
\text { (Milli-units per g.) }\end{array}$ \\
\hline $\begin{array}{l}20 \\
35 \\
50 \\
80\end{array}$ & $\begin{array}{c}7.36 \\
14.88 \\
33.00 \\
50.50 \\
\text { Residue }=21.3 \mathrm{mg} .\end{array}$ & $\begin{array}{c}50 \\
20 \\
\text { No detectable activity } \\
\text { " } \quad \text { Less than } 25 \text { " }\end{array}$ \\
\hline
\end{tabular}

- The antidiuretic activities were kindly established by Dr. J. M. Walker, of the Department of Pharmacology, Oxford. 
according to the method of Ames, Moore, and Van Dyke (1950).

Samples of these fractions were subjected to paper electrophoresis. Although some fractions showed regions of greater staining intensity than in the original strip, no separation into discrete single peptides could be obtained.

An attempt was also made to elute the individual region from paper electrophoretic patterns and concentrate the eluates. These concentrates, however, when again subjected to electrophoresis failed to run uniformly.

\section{Discussion}

The above experiments suggest that the urinary material is very complex with considerable resemblance between the fractions. It is therefore probable that each method of separation fractionated the material differently. Under no circumstances could a substance of appreciable antidiuretic activity be isolated. There is undoubtedly some relationship between the mucopolysaccharides obtained from urine by Anderson and Maclagan (1955) and Tamm and Horsfall $(1950,1952)$. The fact that the glycoproteins described also fail to be coagulated by heat suggests that this property may be largely due to the high carbohydrate content of the material rather than to its hexosamine content. It is difficult to assess the origin of the substance. The experiments described make it clear that it is unlikely to be related to the antidiuretic substance isolated from the posterior pituitary gland. It is, however, likely to be closely related to one of the fractions isolated by Rimington (1940) from plasma after removal of heatcoaguable proteins.

The material described is to a minor degree excreted by normal individuals. Boulanger, Biserte, and Courtot (1952) found that normal persons excreted several peptides, which they classified as dialysable and non-dialysable. Polypeptides were separated from peptides by cadmium chloride fractionation. Hydrolysis of the peptide fractions yielded as the most abundant amino-acids glycine and glutamic acid. There is certainly some relationship with the mucoprotein fractions A1 and A2 recently described by Anderson and Maclagan (1955). When isolated from the urine of 10 normal individuals approximately $36 \mathrm{mg}$. was excreted per 24-hour period. No allowance was made for the possible variations due to sex. A similar group of burned patients excreted approximately $85 \mathrm{mg}$. per 24-hour period. The material obtained from the normal subjects did not appear to differ qualitatively on electrophoretograms. This suggests that there is in burns an increase in excretion of a substance normally present in urine. Increased tissue destruction is known to increase the serum mucoprotein content. Such increases were found in cases of tumours. Gersh and Catchpole (1949) and Catchpole (1950) suggested that these serum mucopolysaccharides are formed by a process of depolymerization which produces water-soluble glycoproteins. Keyser (1952a and b) found the glycoproteins of serum elevated in patients after burning. This material was found to be nondialysable; if it is the source of the urinary material some degradation must have occurred. Some glycoproteins migrate at comparable speed to $\alpha_{2}$ globulins electrophoretically. There may therefore be some association between the increase of $\alpha_{2}$ globulins and the appearance of the substance in the urine, as such a rise occurs soon after burning.

\section{Summary}

A peptide fraction of relatively high carbohydrate content has been isolated from the urine of burned patients.

This material has been subjected to various analyses.

Its relationship to an antidiuretic substance isolated from the posterior pituitary gland has been investigated. The urinary substance showed little antidiuretic activity.

The carbohydrate components of the urinary material were identified and estimated.

The possible relationship of the urinary material isolated with certain glycoproteins is discussed.

I should like to thank Dr. J. P. Bull, Director of the above Unit, for many stimulating discussions and encouragement given.

\section{REFERENCES}

Albon, N., and Gross, D. (1952). Analyst, 77, 410.

Ames, R. G., Moore, D. H., and Van Dyke, H. B. (1950). Endo-

crinology, 46, 215.
Anderson, A. J., and Maclagan, N. F. (1955). Biochem. J., 59, 638.

Arneil, G. C., and Wilson, H. E. C. (1953). Lancet, 1, 568.

Baar, S. (1954). Biochem. J., 58, 175.

Barlow, A. D. (1952). Arch. Dis. Childh., 27, 299.

Boulanger. P., Biserte, G., and Courtot, F. (1952). Bull. Soc. Chim. biol. (Paris), 34, 366.

Bull, J. P., and England, N. W. J. (1954). Lancet, $2,9$.

Bull, J. P., and England, N. W. J. (1954). Lancet, 2. 9.

Catchpole, H. R. (1950). Proc. Soc. exp.
Dent, C. E. (1948). Biochem. J.. 43, 169.

Fiske, C. H., and Subbarow, Y. (1925). J. biol. Chem., 66, 375.

Gersh, I., and Catchpole, H. R. (1949). Amer. J. Anat., 85, 457.

Grollman, A., and Woods, B. (1949). Endocrinology, 44, 409.

Keyser, J. W.' (1952a). Biochem. J., 51, lxvi.

(1952b). Journal of Clinical Pathology, 5, 194

Moore, S., and Stein, W. H. (1948). J. biol. Chem., 176, 367

Rimington, C. (1940). Biochem. J., 34, 931 .

Tamm, I., and Horsfall, F. L. (1950). Proc. Soc. exp. Biol. (N.Y.). 74, 108 . 74, 108. (1952). J. exp. Med., 95, 71.

Tiselius, A., and Hagdahl, L. (1950). Acta chem. scand., 4, 394. 